\title{
Presentación del número
}

Este número de Interpretatio. Revista de Hermenéutica fue elaborado en el contexto de la pandemia del CoviD-19, que ha obligado a repensar el sentido del trabajo académico y ha vuelto más necesaria que nunca la apuesta por el acceso abierto a las investigaciones realizadas dentro de las universidades públicas. En ese contexto, el número presenta un dossier en homenaje al gran pensador y traductor cubano Desiderio Navarro, fallecido en 2017, quien supo crear como pocos canales de discusión plurales y de honda vocación democrática. Este es el segundo de los dossiers que dedicamos a clásicos contemporáneos de la teoría latinoamericana de los últimos años, tema que continuaremos en los próximos números de la revista.

Los artículos de Leonarda Rivera y Enrique Flores exploran la potencia viva de dos textos de la época virreinal: El burlador de Sevilla y la Brevísima relación de la destrucción de las Indias, que son apreciados con una lectura que acentúa sus características más contemporáneas. El texto de Renato Huarte Cuéllar continúa con una preocupación presentada en otros números de Interpretatio al proponer una lectura en clave intercultural que permite comprender las motivaciones del pensador romántico Wilhelm von Schlegel para traducir al latín la Bhagavadgītā. Los artículos de Iram Isaí Evangelista Ávila y María Rosa Palazón proponen abordajes a la teoría hermenéutica en aspectos relacionados con la dinámica de la metáfora y el símbolo y la experiencia profunda del mal. En el contexto de la crisis derivada de la pandemia del covid-19, Manuel Lavaniegos pasa revista críticamente a un ciclo de conferencias impartido recientemente por Jean-Jacques Wunenburger, y aprovecha para proponer, a partir de estas, el cultivo de un nuevo imaginario de la naturaleza capaz de proveer, incentivar y orientar nuestras experiencias sensibles y afectivas, conscientes y racionales, respecto de las relaciones, ahora desgarradas, entre la humanidad y el mundo natural.

En esta ocasión, la obra artística de Saúl Rodríguez Montante M. ilustra nuestro número. Una pequeña muestra de su paisaje abstracto en acuarela que nos transporta a horizontes contemplativos de nuestras serranías.

Comité Editorial de Interpretatio. Revista de Hermenéutica 